\title{
PUTUSAN MAHKAMAH KONSTITUSI TENTANG PENETAPAN STATUS TERSANGKA SEBAGAI OBJEK PRAPERADILAN DALAM PRAKTIK DI PENGADILAN NEGERI PURWOKERTO (Studi Kasus Putusan Praperadilan No. 4/Pid.pra/2015/PN. Pwt) Oleh: Beny Timor Prasetyo
}

\begin{abstract}
The Constitutional Court is one of the perpetrators of the powers of the judiciary among others authorized to adjudicate on the first and last level that an award is final to examine legislation against the Constitution of 1945. Determination of whether a suspect could be debated as part of a pretrial objects end with the existence of a ruling of the Constitutional Court Docket Number 21/PUU-XII/2014 date 28 April 2015.

Normative J uridical Approach: Research. The type of research used in this study is a descriptive analysis. The source of the data in this study is secondary data, and qualitative Data Analysis techniques are normative.

Fine points of consideration and decision of the judge of the Constitutional Court in its Ruling No. 21/PUU-XII/2014 date 28 April 2015, about testing a number of CODE of CRIMINAL PROCEDURE Article specifically about the authority of pretrial Article 77 a CODE of CRIMINAL PROCEDURE and the interpretation of the phrase "evidence of the beginning", "the beginnings of proof enough", and "sufficient evidence" as mentioned in article 1 point 2, article 17 and article 21 paragraph (1) of the CODE of CRIMINAL PROCEDURE, it was decided as follows :1) object praperadailan the authority of article 77 paragraph (1) of the CODE of CRIMINAL PROCEDURE, set expanded including the determination of the suspects, searches and seizures; 2) phrase "the beginning", "proof of evidence of the beginning of a fairly", and "sufficient evidence" as specified in article 1 point 2, article 17 and article 21, paragraph (1) of the CODE of CRIMINAL PROCEDURE, must be a minimum of two is meant evidence contained in article 184 CRIMINAL PROCEDURE CODE ; 3 ) the process of determination of suspects by investigators should be based on a minimum of two evidence contained in the CODE of CRIMINAL PROCEDURE Article 184 (eyewitness description; experts; mail; instructions; description of the defendant).
\end{abstract}

\begin{abstract}
Abstrak
Mahkamah Konstitusi adalah salah satu pelaku kekuasaan kehakiman yang antara lain berwenang mengadili pada tingkat pertama dan terakhir yang putusannya bersifat final untuk menguji undang-undang terhadap Undang-Undang Dasar 1945. Polemik boleh tidaknya penetapan tersangka dijadikan sebagai objek praperadilan berakhir dengan adanya putusan Mahkamah Konstitusi Perkara Nomor 21/PUU-XII/2014 tanggal 28 April 2015.

Pendekatan Penelitian:Yuridis Normatif. Tipe penelitian yang digunakan dalam penelitian ini adalah bersifat deskriptif analisis.Sumber data dalam penelitian ini adalah data sekunder, dan Teknik Analisis Data normatif kualitatif.

Pokok-pokok pertimbangan dan putusan Hakim Mahkamah Konstitusi dalam Putusan No. 21/PUU-XII/2014 tanggal 28 April 2015, tentang Pengujian sejumlah Pasal KUHAP khususnya tentang wewenang praperadilan Pasal 77 huruf a KUHAP dan penafsiran frasa "bukti permulaan", "bukti permulaan yang cukup", dan "bukti yang cukup" sebagaimana disebutkan dalam Pasal 1 angka 14, Pasal 17 dan Pasal 21 ayat (1) KUHAP, diputuskan sebagai berikut: 1) Objek kewenangan praperadailan Pasal 77 ayat (1) KUHAP, ditetapkan diperluas termasuk penetapan tersangka, penggeledahan dan penyitaan; 2) Frasa "bukti permulaan","bukti permulaan yang cukup", dan "bukti yang cukup" sebagaimana ditentukan dalam Pasal 1 angka 14, Pasal 17, dan Pasal 21 ayat (1) KUHAP, harus dimaknai minimal dua alat bukti yang termuat dalam Pasal 184 KUHAP; 3) Proses penetapan tersangka oleh penyidik harus didasarkan pada minimal dua alat bukti yang termuat dalam Pasal 184 KUHAP (keterangan saksi; keterangan ahli; surat; petunjuk; keterangan terdakwa).

Kata kunci: bukti permulaan, putusan hakim, praperadilan
\end{abstract}




\section{A. Latar B elakang}

Menurut

pendapat

R.

Soeparmono, bahwa keberadaan

lembaga praperadilan dalam sistem peradilan pidana adalah merupakan alat kontrol oleh hakim terhadap tindakan-tindakan hukum selama proses penyidikan dan penuntutan yang dilakukan oleh kepolisian dan kejaksaan. ${ }^{1}$ Praperadilan telah diatur dalam Pasal 1 butir 10 jo Pasal 77 KUHAP yang menyatakan bahwa, Praperadilan adalah wewenang pengadilan negeri untuk memeriksa dan memutus menurut cara yang diatur dalam undang-undang ini, tentang:

a. Sah atau tidaknya suatu penangkapan dan atau penahanan atas permintaan tersangka atau keluarganya atau pihak lain atas kuasa tersangka.

b. Sah atau tidaknya penghentian penyidikan atau penghentian penuntutan atas permintaan demi tegaknya hukum dan keadilan.

c. Permintaan ganti kerugian atau rehabilitasi oleh tersangka atau keluarganya atau pihak lain atas kuasanya yang perkaranya tidak diajukan ke pengadilan.

\section{Pasal 77 KUHAP}

Pengadilan Negeri berwenang untuk memeriksa dan memutus, sesuai dengan ketentuan yang diatur dalam undang-undang ini tentang:

a. Sah atau tidaknya penangkapan, penahanan, penghentian penyidikan atau pengentian penuntutan

b. Ganti kerugian dan atau rehabilitasi bagi seorang yang perkara pidananya dihentikan pada tingkat penyidikan atau penuntutan.

R. Soeparmono, 2003. Praperadilan dan Penggabungan Perkara Gugatan Ganti Kerugian Dalam KUHAP, Mandar Maju, Bandung.hlm. 15
Selanjutnya dalam Pasal 78 KUHAP, menyatakan bahwa:

(1) Yang melaksanakan wewenang pengadilan negeri sebagaimana dimaksud dalam Pasal 77 adalah praperadilan.

(2) Praperadilan dipimpin oleh hakim tunggal yang ditunjuk oleh ketua pengadilan negeri dan dibantu oleh seorang panitera.

Salah satu asas terpenting dalam Hukum Acara Pidana ialah asas "praduga tak bersalah". Bersumber dari asas praduga tak bersalah, maka jelas dan wajarlah bila tersangka/terdakwa dalam proses peradilan pidana wajib mendapatkan hak-haknya. Ini berarti bahwa setiap orang yang disangka, ditangkap, ditahan, dituntut dan/atau dihadapkan di depan pengadilan wajib dianggap tidak bersalah sebelum adanya putusan pengadilan yang menyatakan kesalahannya dan telah mem- peroleh kekuatan hukum tetap.

Sebagai seseorang yang belum dinyatakan bersalah, maka ia mendapat hak-hak seperti hak untuk segera mendapatkan pemeriksaan dalam tahap penyidikan, hak segera mendapat peme- riksaan oleh pengadilan dan mendapatkan putusan seadil-adilnya, hak untuk diberitahu tentang apa yang disangkakan/didakwakan, hak untuk menyiapkan pembelaannya, hak untuk menda- patkan bantuan hukum dan hak untuk mendapatkan kunjungan keluarganya, sesuai dengan tujuan KUHAP yang memberi perlindungan kepada hak-hak asasi dalam 
463 | J urnal Idea Hukum

Vol. 2 No. 2 Oktober 2016

Magister Hukum Fakultas Hukum Universitas J enderal Soedirman

keseimbangan dengan kepentingan

umum. Dengan lahirnya lembaga baru

dalam KUHAP yang disebut

praperadilan, maka tersangka

dilindungi dalam pemeriksaan penda-

huluan terhadap tindakan-tindakan ke-

polisian dan atau kejaksaan, yang me-

langgar hukum dan merugikan

tersangka.Di samping itupraperadilan sebagai lembaga baru berfungsi sebagai alat kontrol dari penyidik terhadap penyalahgunaan wewenang yang diberikan kepadanya. ${ }^{2}$

Mahkamah Konstitusi adalah salah satu pelaku kekuasaan kehakiman yang antara lain berwenang mengadili pada tingkat pertama dan terakhir yang putusannya bersifat final untuk menguji undang-undang terhadap UUD 1945. Wewenang tersebut diatur dalam Pasal 10 ayat (1) UU No. 24 Tahun 2003 tentang Mahkamah Konstitusi sebagaimana diubah dengan UU No. 8 Tahun 2011 tentang Perubahan UU No. 24 Tahun 2003 tentang Mahkamah Konstitusi, yang berbunyi sebagai berikut:

"Mahkamah Konstitusi berwenang mengadili pada tingkat pertama dan terakhir yang putusannya bersifat final untuk:

- menguji undang-undang terhadap Undang-Undang Dasar Tahun 1945;

- memutus sengketa kewenangan lembaga negara yang kewenangannya diberikan oleh Undang-undang Dasar Negara Republik Tahun 1945;

S. Tanusubroto, 2006. Peranan Praperadilan dalam Hukum Acara Pidana, Alumni, Bandung, hlm. 1
- memutus pembubaran partai politik; dan

- memutus perselisihan tentang hasil pemilihan umum.

Dari wewenang menguji undangundang (toetsingrecht) terhadap UUD 1945 tersebut Mahkamah Konstitusi dapat membuat hukum baru yang berlaku umum dalam hal undangundang yang diperiksa bertentangan dengan UUD 1945. Pembentukan hukum baru oleh Mahkamah Konstitusi tersebut dilandasi oleh ideide dasar dalam rangka mewujudkan tujuan hukum, yaitu keadilan, kepastian dan ke- manfaatan dalam masyarakat. Ide dasar pembentukan hukum baru dapat dijadikan sebagai tolok ukur berhasil tidaknya tujuan hukum tersebut dicapai. ${ }^{3}$

Polemik boleh tidaknya penetapan tersangka dijadikan sebagai objek praperadilan berakhir dengan adanya putusan Mahkamah Konstitusi Perkara Nomor 21/PUUXII/2014 tanggal 28 April 2015 yang memeriksa permohonan pengujian UU No. 8 Tahun 1981 tentang Hukum Acara Pidana ter- hadap UUD Tahun 1945 yang diajukan oleh Bachtiar Abdul Fatah.Permasa- Iahan utama dalam putusan Mahka- mah Konstitusi No. 21/PUU-XII/2014 tanggal 28 April 2015 adalah pengujian konstitusionalitas Pasal 1 angka 2, Pasal 1 angka 14, juncto Pasal 17, Pasal 21 ayat (1) Pasal 77 huruf a, dan

3 M. Sholehudin, 2004. Sistem Sanksi dalam Hukm Pidana. Ide Dasar Doble Track System \& Implementasinya, Raja Grafindo, Jakarta, hlm. 23 
Pasal 156 ayat (2) KUHAP, bahwa dasar pengujian permohonan ini adalah Pasal 1 ayat (3), Pasal 28D ayat (1), dan Pasal 28I ayat (5), dan Pasal 28J ayat (2) UUD 1945.

Putusan Praperadilan Pengadil-

an Negeri Purwokerto Nomor 4/Pid.Pra/2015/PN. Pwt, tanggal 25 Agustus 2015, permohonan praperadilan yang diajukan oleh Thio Raharjo al. Thio Woengim dengan permasalahan pokok praperadilan, Pemohon telah dite- tapkan sebagai Tersangka oleh Termohon, yang diawali adanya Laporan Polisi oleh Sutiono (pelapor) terhadap Pemohon, dengan diduga Pemohon telah melakukan perbuatan peng- gelapan dan atau penipuan berupa 6 (enam) SHM dan uang milik pelapor Sutiono sebesar Rp 8.000.000.000 (delapan milyar rupiah).

Setelah dilakukan penelitian dalam persidangan yang terkait dengan barang bukti, sebagaimana diduga oleh pelapor (Sutiono) atas diri Pemohon pada tiga Bank yaitu Danamon, BII dan BTN serta 6 (enam) SHM yang diduga milik Sutiono ternyata tidak ada. Dibuktikan oleh pemohon bahwa 6 (enam) SHM yang diduga milik Pelapor ternyata adalah milik Pemohon sehingga dengan demikian dapat sebutkan bahwa yang dijadikan objek dalam perkara pidana menjadi tidak dapat dibuktikan yaitu bahwa 6 (enam) SHM tersebut adalah milik pelapor (Sutiono).
Berdasarkan uraian tersebut di atas, penulis tertarik untuk melakukan penelitian dalam dengan judul: "Penerapan Putusan Mahkamah Konstitusi Tentang Penetapan Status Tersangka Sebagai Objek Praperadilan Dalam Praktik Di Pengadilan Negeri Purwokerto(Studi Kasus Putusan Praperadilan No. 4/Pid.pra/2015/PN. Pwt)".

\section{B. Perumusan Masalah}

1. Apa yang menjadi pokok-pokok pertimbangan Hakim Mahkamah Konstitusi dalam Putusan MK No. 21/PUU-XII/2014?

2. Bagaimana pertimbangan Hakim Pengadilan Negeri Purwokerto dalam memutus Perkara Praperadilan No. 4/Pid.pra/2015/PN. Pwt ditinjau dari pertimbangan Hakim MK dalam Putusan MK No. 21/PUU-XII/2014?

\section{Metode Penelitian}

Pendekatan Penelitian:Yuridis Normatif. Tipe penelitian yang digunakan dalam penelitian ini adalah bersifat deskriptif analisis yaitu penelitian yang menggambarkan peraturan perundang-undangan yang berlaku yang dikaitkan dengan teori-teori hukum positif yang menyangkut perasalahan yang sedang diteliti. ${ }^{4}$ Sumber data dalam penelitian ini adalah data sekunder yaitu data yang bersifat kepustakaan, data yang

\footnotetext{
Ronny Hanitijo Soemitro, 1988. Metode Penelitian Hukum dan Yurimetri. Ghalia Indonesia, Jakarta. hlm. 98
} 
465 | J urnal Idea Hukum

Vol. 2 No. 2 Oktober 2016

Magister Hukum Fakultas Hukum Universitas J enderal Soedirman

biasanya telah tersusun dalam bentuk

dokumen-dokumen. Sumber data sekunder antara lain mencakup bahan hukum primer berupa Undang-undang seperti KUHP, KUHAP, Peraturan Mahkamah Agung dan Putusan-putusan pengadilan. ${ }^{5}$ Teknik Analisis Data normatif kualitatif. Pendapat Soerjono Soekanto berkaitan dengan analisis data kualitatif adalah analisis yang bertujuan untuk mengungkapkan apa yang menjadi latar belakang kebenaran. Dengan demikian jumlah (kuantitas) data sekunder tidak dituamakan melainkan kualitas data sekunder, yaitu data yang diperoleh dari studi kepustakaan. ${ }^{6}$

\section{Hasil Penelitian dan Pembahasan}

1. Pokok-pokok pertimbangan Hakim Mahkamah Konstitusi dalam Putusan MK No. 21/PUUXII/2014

Agar putusan dapat dipertanggungjawabkan, maka putusan harus memenuhi standar teori ilmu hukum, moral dan etika, keseluruhan proses peradilan harus dilakukan secara cermat dan matang, fakta-fakta harus digeledah dan dibedah oleh hakim, fakta tersebut dianalisis secara matang dan maksimal, yang dituangkan dalam pertimbangan hukum, pertimbangan hukum adalah konkritisasi alur pikir hakim dalam memberikan putusan yang

5 Bambang Sunggono, 2006. Metode Penelitian Hukum, Raja Grafindo Persada, Jakarta. hlm. 35

6 Soerjono Soekanto, Op. cit. hlm. 25 didasarkan dari fakta-fakta tersebut. $^{7}$

Mahkamah Konstitusi menjatuhkan putusan dalam permohonan Pengujian KUHAPterhadap Undang-Undang Dasar 1945, yang diajukan oleh Bachtiar Abdul Fatah, Pekerjaan Karyawan PT. Chevron Pasific Indonesia, Alamat Komplek Merapi Nomor 85, RT 01/RW 03, Desa Pematang Kudu, Kecamatan Mandau, Bengkalis, Riau.

Permohonan pengujian (constitution al review)KUHAP terhadap UUD 1945, dalam gugatan dinyatakan adanya sejumlah pasal yangbermasalah meliputi Pasal 1 angka (2), Pasal 1 angka 14, Pasal 17, Pasal 21 ayat (1), Pasal 77 huruf a dan Pasal 156ayat (2) KUHAP, karena pasal-pasal yang diuji telah merugikan hak-hak konstitusional pemohon. Dasar pengujian adalah Pasal 1 ayat (3), Pasal 28D ayat (1), Pasal 28I ayat (5), dan Pasal 28J ayat (2) UUD 1945.

Mengenai pengujian Pasal 1 angka 2 KUHAP yang menyatakan:"Penyidikan adalah serangkaian tindakan penyidik dalam hal dan menurut cara yang diatur dalam undang-undang ini untuk mencari serta mengumpulkan

\footnotetext{
Muhammad Rizki, Epistemologi Nalar dalam Pertimbangan Hukum, Majalah Hukum Varia Peradilan No. 346, Edisi Spetember 2014, Mahkamah Agung RI, Jakarta, hlm. 56
} 
bukti yang dengan bukti itu mem-

buat terang tindak pidana yang terjadi dan guna menemukan tersangkanya".

Pemohon dalam permohonannya mendalilkan bahwa frasa "dan guna menemukan tersangkanya" dalam Pasal 1 angka 2 KUHAP melanggar Pasal 1 ayat (3) dan Pasal 28D ayat (1) UUD 1945 karena menimbulkan kesewenang-wenangan sehingga bertentangan dengan prinsip due process of law serta melanggar hak atas kepastian hukum yang adil. Menurut Mahkamah, dalil Pemohon a quo tidak beralasan menurut hukum.

Pasal 1 angka 2 KUHAP mengatur bagaimana penyidik menemukan tersangka sehingga pasal tersebut sudah jelas dan tidak perlu ditafsirkan. Frasa "dan guna menemukan tersangkanya", menurut Mahkamah, sebenarnya sudah dipenuhi oleh pasal tersebut, yaitu penyidik dalam rangkaian tindakan penyidikan melakukan suatu proses pengumpulan bukti yang dengan bukti tersebut kemudian penyidik menemukan tersangka dalam satu tindak pidana sehingga tidak serta merta penyidik menemukan tersangka sebelum melakukan pengumpulan bukti sebagaimana ditentukan dalam pasal a quo.

Norma tersebut sudah tepat karena memberikan kepastian hukum yang adil kepada Warga Negara Indonesia ketika akan ditetapkan menjadi tersangka oleh penyidik, yaitu harus melalui proses atau rangkaian tindakan penyidikan dengan cara mengumpulkan bukti yang dengan bukti tersebut penyidik menemukan tersangkanya, bukan secara subjektif penyidik menemukan tersangka tanpa mengumpulkan bukti. Menurut Mahkamah, dalil Pemohon a quo bahwa frasa "dan guna menemukan tersangkanya" dalam Pasal 1 angka 2 KUHAP melanggar Pasal 1 ayat (3) dan Pasal 28D ayat (1) UUD 1945 adalah tidak beralasan menurut hukum.

Terhadap pengujian frasa "bukti permulaan", "bukti permulaan yang cukup", dan "bukti yang cukup" sebagaimana ditemukan dalam Pasal 1 angka 14, Pasal 17, dan Pasal 21 ayat (1) KUHAP bertentangan dengan Pasal 1 ayat (3), Pasal 28D ayat (1), dan Pasal 28I ayat (5) UUD 1945.

Pertimbangan Makhamah yang menyertakan pemeriksaan calon tersangka di samping minimum dua alat bukti tersebut di atas, adalah untuk tujuan transparansi dan perlindungan hak asasi seseorang agar sebelum seseorang ditetapkan sebagai ter- sangka sudah dapat memberikan keterangan yang seimbang deng- an minimum dua 
467 | J urnal Idea Hukum

Vol. 2 No. 2 Oktober 2016

Magister Hukum Fakultas Hukum Universitas J enderal Soedirman

alat bukti yang telah ditemukan

oleh penyidik. Berdasarkan

alasan tersebut di atas, seorang

penyidik di dalam menentukan

"bukti permulaan", "bukti

permulaan yang cukup", dan

"bukti yang cukup" sebagaimana

yang dimaksud dalam Pasal 1

angka 14, Pasal 17, dan Pasal 21

ayat (1) KUHAP dapat dihindari

adanya tindakan sewe- nang-

wenang, terlebih lagi di dalam

menentukan bukti permulaan

yang cukup selalu dipergunakan

untuk pintu masuk bagi seorang

penyidik di dalam menetapkan

seseorang menjadi tersangka.

Menurut Mahkamah dalil

Pemohon a quo beralasan

menurut hukum.

Mengenai pengujian Pasal
77 huruf a KUHAP yang menyatakan: "Pengadilan negeri berwenang untuk memeriksa dan memutus, sesuai dengan ketentuan yang diatur dakam undangundang ini tentang: (a) sah atau tidaknya penangkapan, penahanan, penghentian penyidikan atau penghentian penuntutan", menu- rut pemohon Pasal 77 huruf a KUHAP bertentangan dengan Pasal 1 ayat (3), Pasal 28D ayat (1), dan Pasal 28I ayat (5) UUD 1945 apabila tidak dimaknai mencakup sah atau tidak sahnya penetapan tersangka, pengge- ledahan, penyitaan, dan pemeriksaan surat.

Berkaitan dengan penetapan tersangka, Mahkamah mempertimbangkan dalil pemohon bahwa Pasal 77 huruf a KUHAP bertentangan dengan Pasal 1 ayat (3), Pasal 28D ayat (1), dan Pasal 28I ayat (5) UUD 1945 apabila tidak dimaknai mencakup sah atau tidak sahnya penetapan tersangka, penggeledahan, penyi- taan, dan pemeriksaan surat, Mahkamah berpendapat:

1) Mengenai penetapan tersangka.

Menurut Mahkamah, dalil Pemohon mengenai penetapan tersangka menjadi objek yang diadili oleh pranata prapera- dilan adalah beralasan me- nurut hukum.

2) Sepanjang menyangkut penggeledahan dan penyitaan, Mahkamah dalam Putusan Nomor 65/PUU-IX/2011, bertanggal 1 Mei 2012, yang mengadili dalam kaitannya dengan Pasal 83 ayat (2) KUHAP

Secara implisit Mahkamah sesungguhnya sudah menyatakan pendapatnya bahwa penggeledahan dan penyitaan me- rupakan bagian dari mekanis- me kontrol terhadap kemung- kinan tindakan sewenang-wenang dari penyidik atau penuntut umum dan karenanya termasuk dalam ruang lingkup praperadilan. Oleh karena itu, permohonan pemohon mengenai penggeledahan dan penyitaan beralasan menurut hukum. 
3) Adapun mengenai pemeriksaan surat seperti yang telah didalilkan pemohon agar masuk dalam ruang lingkup kewenangan pranata praperadailan, menurut Mahkamah, pemeriksaan surat tersebut merupakan bagian yang tidak terpisahkan dari tindakan penggeledahan dan penyitaan, sehingga pertimbangan Mahkamah pada angka 2 di atas berlaku pula terhadap dalil pemohon a quo.

Berdasarkan penilaian

hukum dan fakta tersebut di atas,

kemudian Mahkamah Konstitusi berkesimpulan dan memutuskan dalam Putusan Nomor 21/PUUXII/2014, perkara pengujian beberapa pasal dalam KUHAP terhadap Undang-Undang Dasar 1945, sebagai berikut:

a. Frasa "bukti Permulaan","bukti permulaan yang cukup", dan "bukti yang cukup" sebagaimana ditentukan dalam Pasal 1 angka 14, Pasal 17, dan Pasal 21 ayat (1) KUHAP, bertentangan dengan Undang-Undang Dasar Negara 1945 sepanjang tidak dimaknai bahwa "bukti permulaan", "bukti permulaan yang cukup", dan "bukti yang cukup" adalah minimal dua alat bukti yang termuat dalam Pasal 184 Undang-undang Nomor 8 Tahun 1981 tentang Hukum Acara Pidana;

b. Frasa "bukti permulaan", "bukti permulaan yang cukup", dan "bukti yang cukup" sebagaimana ditentukan dalam Pasal 1 angka 14, Pasal 17, dan Pasal 21 ayat (1) KUHAP tidak mempunyai kekuatan hukum mengikat sepanjang tidak dimaknai bahwa "bukti permulaan","bukti permulaan yang cukup", dan "bukti yang cukup" adalah minimal dua alat bukti yang termuat dalam Pasal 184 KUHAP;

c. Pasal 77 huruf a KUHAP, bertentangan dengan UUD1945 sepanjang tidak dimaknai termasuk penetapan tersangka, penggeledahan, dan penyitaan;

d. Padal 77 huruf a KUHAP tidak mempunyai kekuatan hukum mengikat sepanjang tidak dimaknai termasuk penetapan tersangka, penggeledahan, dan penyitaan;

Dalam putusan Mahkamah No. 21/PUU-XII/2014 ini terdapat satu orang Hakim Konstitusi yang memiliki alasan berbeda (Concurring Opinion). ArtidjoAlkostar, mengartikan Concurring Opinion sebagai suatu pendapat yang dikemukakan oleh seorang atau lebih hakim yang setuju dengan pendapat mayoritas yang menjadi putusan pengadilan, tetapi memberikan pertimbangan yang berbeda. $^{8}$ Hakim Konstitusi dimaksud adalah Patrialis Akbar, yang memiliki alasan berbeda sebagai berikut:

Pertimbangan hukum Mahkamah dalam perkara a quo sudah tepat, apalagi sudah dirumuskan oleh Rapat Permusyawarahan Hakim. Putusan Mahkamah a quo mengutamakan rasa keadilan dan kemanusiaan. Salah satu permohonan pemohon adalah memasukkan penetapan tersangka dalam objek praperadilan dan dikabulkan oleh

8 ArtidjoAlkostar, 2008 Dissenting Opinion, Concurring Opinion dan Pertanggungjawaban Hakim, Majalah Varia Peradilan No. 268 Edisi Maret 2008, IKAHI, Jakarta. hlm. 23 
469 | J urnal Idea Hukum

Vol. 2 No. 2 Oktober 2016

Magister Hukum Fakultas Hukum Universitas J enderal Soedirman

Mahkamah, hal ini justru memperkuat tekad untuk mengakui, menghormati, menjamin dan melindungi terhadap Hak Asasi Manusia yang berkaitan khususnya tentang mekanisme dan proses terhadap seseorang ditetapkan sebagai tersangka.

Mendukung dan setuju dengan putusan Mahkamah dalam perkaraa quo, tetapi akan lebih tepat jika hal ini diserahkan pada pembentuk undang-undang untuk menentukan pilihan objekobjek praperadilan asal sejalan dan tidak bertentangan dengan kons- titusi dengan memperhatikan sungguh-sungguh pertimbangan hukum Mahkamah a quo. Hal ini sebenarnya merupakan kebijakan hukum terbuka pembentuk Un- dangundang (O pen legal policy).

Dalam putusan Mahkamah No. 21/PUU-XII/2014 ini, terdapat tiga orang Hakim Konstitusi yang memiliki pendapat berbeda (Dissenting Opinion). Pada hakikatnya dissenting opinion adalah merupakan perbedaan pendapat yang terjadi antara majelis hakim yang menangani suatu kasus tertentu dengan majelis hakim lainnya yang menangani kasus tertentu lainnya. Majelis hakim yang me- nangani suatu perkara menurut kebiasaan dalam hukum acara berjumlah 3 (tiga) orang, dari ketiga orang anggota majelis hakim ini apabila dalam musyawarah menjelang pengambilan putusan terdapat perbedaan pendapat di antara satu sama lain maka putusan akan diambil dengan jalan voting atau kalau hal ini tidak memungkinkan, pendapat hakim yang paling menguntungkan bagi terdakwa yang akan dipakai dalam putusan. Sedangkan bagi hakim anggota yang kalah suara dalam menentukan putusan, harus menerima pendapat mayoritas majelis hakim dan dapat menuliskan pendapatnya yang berbeda dengan putusan dalam buku khusus yang dikelola oleh Ketua Pengadilan Negeri dan bersifat rahasia. ${ }^{9}$ Bila diartikan maka "dissenting opinion" adalah terjadinya perbedaan pendapat atas suatu persoalan hukum.

Perbedaan pendapat (Dissenting Opinion) dalam putusan Mahkamah No. 21/PUU-XII/2014 ini, disampaikan oleh:

a. Hakim Konstitusi I Dewa Gede Palguna, menyatakan:

Bahwa tidak masuknya penetapan tersangka ke dalam ruang lingkup praperadilan telah ternyata tidak bertentangan dengan Pasal 1 ayat (3), Pasal 28D ayat (1), dan Pasal 28I ayat (5) UUD 1945 oleh karena itu, sepanjang menyangkut dalil pemohon yang didalilkan penetapan tersangka merupakan bagian dari ruang lingkup praperadilan, Makhamah seharusnya menolak permohonan a quo.

b. Hakim Konstitusi Muhammad Alim, menyatakan:

Dengan pertimbangan tersebut di atas, sebetulnya apabila prosedurnya sudah

\footnotetext{
MaPPI FHUI, Dessenting opinion,www.pemantauperadilan.com. Diakses pada tanggal 2 Nopember 2015.
} 
benar, maka tanpa memasukkan kewenangan praperadilan untuk memeriksa penetapan menjadi tersangka, sudah benar me- rupakan penegakan HAM. Jadi penetapan menjadi tersangka sebetulnya bukanlah kewenangan praperadilan asal prosedur yang ditetapkan oleh hukum acara pidana dilaksanakan dengan baik.

Jikalau dalam kasus konkrit penyidik ternyata menyalahgunakankewenanga nnya, yakni misalnya secara subjektif menetapkan seseorang menjadi tersangka tanpa mengumpulkan bukti, maka hal tersebut bukan menjadi kewenangan Mahkamah Konstitusi, sebab hal semacam itu merupakan penerapan hukum. Penilaian atas penerapan hukum adalah kewenangan institusi lain, bukan kewenangan Mahkamah Konstitusi.

c. Hakim Konstitusi Aswanto, menyatakan:

Makhmamah berwenang untuk memberikan penafsiran atas suatu norma berdasarkan UUD $1945 . \quad$ Namun, memasukkan penetapan tersangka sebagai objek praperadilan bukanlah persoalan penafsiran. Tidak ada kata atau frasa dalam ketentuan Pasal 77 huruf a KUHAP yang dapat dimaknai sebagai penetapan tersangka atau termasuk penetapan tersangka. Ketentuan a quo sudah sangat jelas mengatur apa saja yang dapat diuji di forum praperadilan. Menjadikan penetapan tersangka sebagai salah satu objek praperadilan yang sebelumnya tidak terdapat dalam KUHAP adalah membuat norma baru yang bukan kewenangan Mahkamah Kons- titusi melainkan kewenangan pembentuk undang-undang.
Tidak diaturnya penetapan tersangka sebagai objek praperadilan dalama Pasal 77 huruf a KUHAP tidak menjadikan ketentuan tersebut inkonstitusional. Apabila penetapan tersangka dipandang dapat lebih menghormati dan menjaga hak asas tersangka, maka gagasan demikian dapat dimasukkan ke dalam ketentuan undang-undang oleh pembentuk undang-undang sesuai dengan kewenangan yang melakat padanya.

\section{Pertimbangan Hakim Pengadilan Negeri Purwokerto dalam memutus Perkara Praperadilan No. 4/Pid.pra/2015/PN. Pwt ditinjau dari pertimbangan Hakim MK dalam Putusan MK No. 21/PUU- XII/2014}

Putusan hakim harus terkandung adanya konsistensi. Konsistensi putusan hakim berdampak pada terciptanya kesamaan hukum dan meminimalisasi perbedaan (disparitas) sehingga penegakan hukum dapat diperkirakan penyelesaian hukumnya. Konsistensi penerapan hukum juga mendorong tumbuhnya yurisprudensi sebagai salah satu sumber hukum utama di Indonesia. Menjadikan yurisprudensi sebagai sumber hukum bukan hanya membaca amar putusan melainkan memahami ratio decidendi (obiterdicta) dalam peraturanperaturan sebelumnya. Pemahaman secara utuh terhadap putusan terdahulu akan mendorong pengembangan pemikiran, ketajaman analisis, 
471 J urnal Idea Hukum

Vol. 2 No. 2 Oktober 2016

Magister Hukum Fakultas Hukum Universitas J enderal Soedirman

penyelesaian masalah secara

jernih. $^{10}$

Pertimbangan hakim Penga-

dilan Negeri Purwokerto dalam

memutus Perkara Praperadilan

No. 4/Pid.pra/2015/PN. Pwt dapat

dikemukakan tentang pokok-

pokok pertimbangan hukum

sebagai berikut:

a. Permasalahan pokok dalam perkara permohonan

praperadilan ini, adalah apakah surat perintah penyidikan yang menetapkan Pemohon sebagai Tersangka oleh Termohon tekait peristiwa pidana seba- gaimana dimaksud dalam Pasal 372 dan/atau Pasal 378 KUHP adalah tidak sah dan tidak berdasar atas hukum? Dan apakah penyidikan a qou yang dilakukan oleh termohon tidak mempunyai kekuatan mengikat?

b. Sebelum menjawab permasalah pokok dalam praperadilan ini, Hakim terlebih dahulu menguraikan asas-asas dalam penyidikan yaitu:

1) Asas legalitas: KUHAP mengandung asas legalitas karena meletakkan kepentingan hukum dan perundang-undangan di atas kepentingan hukum dan perundang-undangan dan persamaan keadilan bang- sa Indonesia, dalam

10 Imam Subechi, 2014. Putusan Hakim dalam Pembaharuan Hukum, Majalah Hukum Varia Peradilan. No. 347 Edisi Oktober 2014, Mahkamah Agung RI, Jakarta, hlm. 25 hal penyidikan, penyidik tidak boleh memberikan perlakuan diskriminatif pada tersangka seperti hak untuk mendapatkan bantuan hukum, hak mendapat kunjungan rohaniawan, hak untuk mendapat perawatan kesehatan yang memadai dan sebagainya;

2) Asas praduga tak bersalah: asas ini disebut dalam Undang-undang No. 14 Tahun 1970 jo Undang-undang No. 4 Tahun 2004 jo Undangundang Nomor 28 Tahun 2009 tentang Ketentuanketentuan Pokok Kekuasaan Kehakiman, dan dalam Penjelasan Umum butir 3 c KUHAP, yang berbunyi : Setiap orang yang disangka, ditangkap, dita- han, dituntut dan atau dihadapkan di muka sidang pengadilan, wajib diang- gap tidak bersalah sampai adanya putusan pengadilan yang menyatakan kesalahannya dan mempe- roleh kekuatan hukum tetap; yang mana cara-cara pemeriksaan yang semula bersifat inquisitoir menjadi aqusatoir, sehing- ga cara penyidikan yang dilakukan dengan meng- gunakan kekerasan sudah tidak sesuai, karena pengakuan terdakwa sudah masuk menjadi alat bukti;

3) Asas cepat, sederhana dan biaya ringan: asas ini memberikan pedoman dan garis batas bagi setiap tahap pemeriksaan. Penjabaran asas ini adalah tercermin pada adanya batas waktu penyelidikan, penyidikan, penuntutan sampai pada proses persidangan hingga berkekuatan hukum tetap, 
selain itu juga ditentukan juga secara tegas batas waktu penahanan tersangka maupun terdakwa; serta asas ini mencerminkan adanya perlindungan hak asasi manusia sekalipun orang tersebut ber-ada dalam kedudukan sebagai tersangka/terdakwa.

Walaupun dalam kondisi dibatasi kemerdekaannya karena ditangkap kemudian ditahan, namun orang tersebut tetap memperoleh kepastian bahwa tahapantahapan pemeriksaan yang dilaluinya memiliki batas waktu yang terukur dan dijamin undangundang;

4) Asas diferensiasi fungsional: yaitu KUHAP dengan tegas mengatur tugas dan wewenang antar aparat penegak hukum, mulai dari tahap permulaan penyidikan oleh kepolisian, penun- tutan, persidangan hingga eksekusi dan pengawasan pengamatan eksekusi. Sehingga dari tahap awal/pertama hingga tahap akhir selalu terjalin hubungan fungsi yang berkelanjutan dan terjadi pula fungsi pengawasan antar satu lembaga penegak hukum dengan lembaga hukum lainnya;

5) Asas saling koordinasi: selain asas deferensiasi tersebut namun tetap ada hubungan koordinasi di antara instansi tersebut dalam rangka jalannya proses penegakan hukum itu sendiri;

6) Asas akusatoir dan inquisitoir: yaitu dalam melakukan pemeriksaan tersang- ka, penyidik tidak diperke- nankan untuk melakukan tekanan dalam bentuk apapun. Namun KUHAP juga tidak menjadikan pengaku- an tersangka sebagai salah satu dari jenis alat bukti; asas aqusatoir yaitu menempatkan tersangka sebagai subjek pemeriksaan, sedangkan inquisitoir tersangka menjadi objek pemeriksaan, sehingga pengakuan menjadi hal yang sangat penting untuk diperoleh oleh penegak hukum;

7) Asas persamaan di muka hukum: dalam pelaksanaannya semua orang harus diperlakukan sama dan tidak boleh dibedakan, baik untuk mendapatkan perlindungan hukum maupun bagi tersangka/terdakwa yang sedang menjalani proses persidangan. Setiap tahap pemeriksaan diberikan jangka waktu limitatif yang secara terang tertulis dalam ketentuan KUHAP dan pelanggaran terhadap ketentuan tersebut dapat dilakukan praperadilan;

c. Dasar penyidikan dalam menjalankan tugas dan wewenangnya diatur oleh KUHAP, berdasarkan Pasal 1 angka 2 KUHAP, penyidikan adalah serangkaian tindakan penyidik dalam hal dan menurut cara yang diatur dalam undang-undang ini untuk mencari serta mengumpulkan bukti yang dengan bukti itu membuat terang tentang tindak pidana yang terjadi dan guna menemukan tersangkanya. 
473 | J urnal Idea Hukum

Vol. 2 No. 2 Oktober 2016

Magister Hukum Fakultas Hukum Universitas J enderal Soedirman

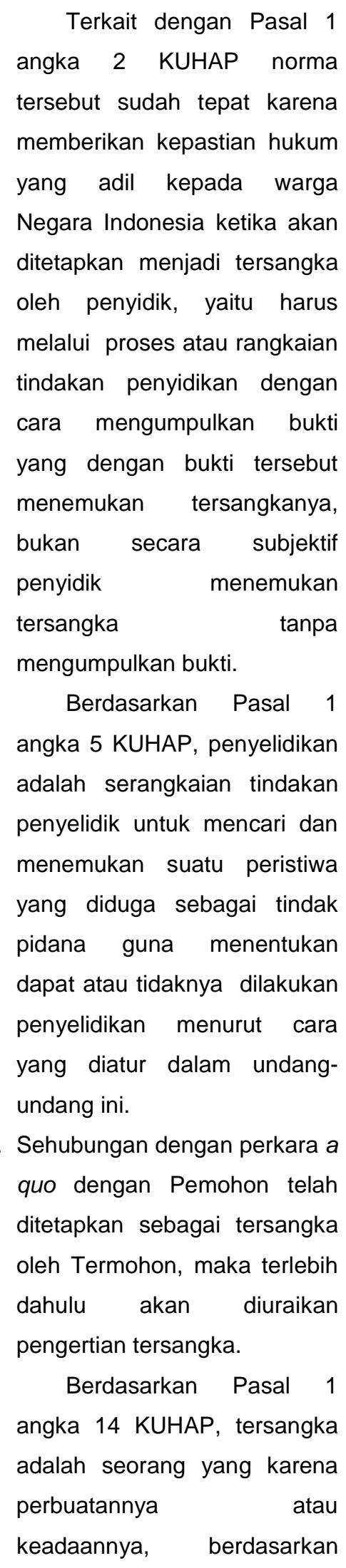

bukti permulaan patut diduga sebagai pelaku tindak pidana.Bukti permulaan dimaknai sebagai berikut : berdasarkan Putusan Mahkamah Konstitusi Nomor 21/PUU-XII/2014 tertanggal 28 April 2015 yaitu:

Agar memenuhi asas kepastian hukum yang adil sebagaimana ditentukan dalam Pasal 28 D ayat (1) UUD 1945 serta memenuhi asas lex certa dan asas lex strica dalam hukum pidana maka frase "bukti permulaan","bukti permulaan yang cukup" dan "bukti yang cukup" sebagiamna ditentukan dalam Pasal 1 angka 14, Pasal 17, dan Pasal 21 ayat (1) KUHAP harus ditafsirkan sekurang-kurangnya dua alat bukti yang termuat dalam Pasal 184 KUHAP dan disertai dengan pemeriksaan calon tersangkanya dimungkinkan dilakukan tanpa kehadiran (in absebtia). Artinya terhadap tindak pidana yang penetapan tersangkanya dimungkinkan dilakukan tanpa kehadirannya tersebut, tidak diperlukan pemeriksaan calon tersangka.

Yang dipermasalahkan dalam penetapan tersangka terhadap diri Pemohon adalah diawali adanya Laporan Polisi oleh Sutiono (Pelapor) terhadap Pemohon, dengan diduga Pemohon telah melakukan perbuatan penggelapan dan atau penipuan berupa enam SHM dan uang milik pelapor sebesar Rp 8.000.000.000,00 (delapan milyar rupiah) dan 


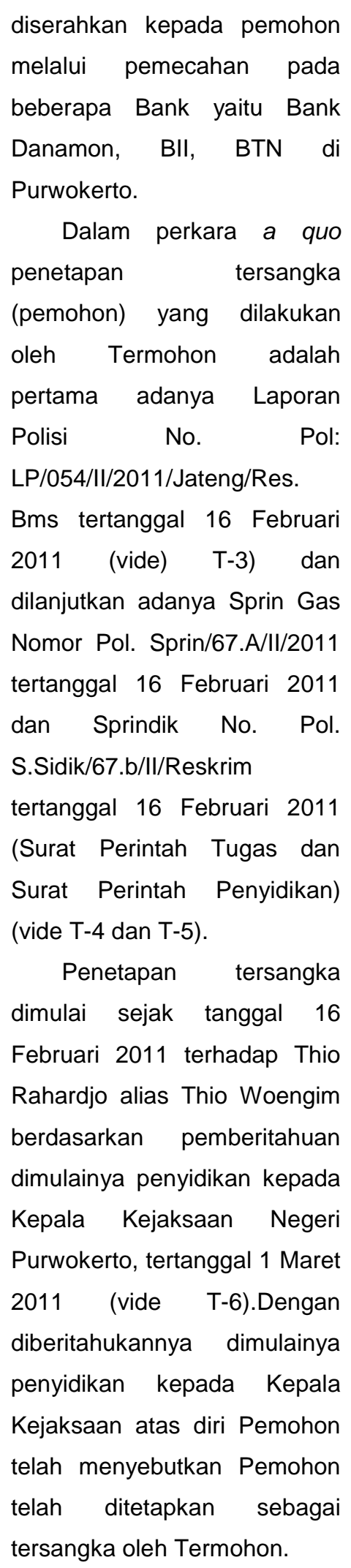

Setelah ditetapkannya Pemohon sebagai tersangka, kemudian Termohon mengumpulkan bukti-bukti, yaitu dengan memeriksa saksi-saksi sebanyak 10 (orang saksi) yang akan diuraikan di bawah ini sebagai berikut:

Pada tanggal 16 Februari 2011 telah diperiksa seorang saksi bernama Subandriyo dan dilanjutkan pemeriksaan saksi pelapor yang bermana Sutiono alias Thio Woen Pao pada tanggal 17 Februari 2011 yang pada pokoknya menerangkan bahwa telah terjadinya tindak pidana penggelapan dan atau penipuan yang dilakukan oleh Pemohon, keterangan yang diberikan oleh Subandriyo diketahui berdasarkan penyampaian Sutiono (saksi pelapor) kepadanya (Subandriyo) keterangan tersebut diberikan berdasarkan pemeriksaan keterangan tambahan tertanggal 04 Februari 2012.

Pada tanggal 19 Februari 2011 telah diperiksa dalam Berita Acara Pemerikasan saksi Parmono, pada tanggal 18 Februari 2011 telah diperiksa dalam Berita Acara Pemeriksaan (BAP) Tri Darwati, dan pada tanggal 2 Maret 2011 telah diperiksa dalam BAPterhadap Esti 
475 | J urnal Idea Hukum

Vol. 2 No. 2 Oktober 2016

Magister Hukum Fakultas Hukum Universitas J enderal Soedirman

Ginawati, serta pada tanggal 2

Maret 2011 telah diperiksa

dalam BAPterhadap saksi

Hartono (vide P-7) yang pada

pokoknya tidak mengetahui

penyerahan SHM dan uang

yang diklaim adalah milik

Sutiono (pelapor).

Tersangka

(Pemohon/Thio Rahadjo alias

Thio Woengim) diperiksa pertama pada tanggal 01 Maret 2012, sampai lima kali kemudian dengan pemeriksaan tambahan, yang didasarkan pada Surat Panggilan terhadap Pemohon tertanggal 07 Februari 2012 dan 27 Februari 2012 (vide P2 dan P-4), serta adanya Surat Panggilan tertanggal 28 September 2012, untuk memberikan keterangan dalam BAP tertanggal 12 Oktober 2012 (vide P-8) dan Surat Panggilan tertanggal 24 Juni 2013. Keterangan mana yang pada pokoknya menerangkan tidak benar dan kepemilikan enam buah SHM yang disimpan oleh Pemohon adalah 3 (tiga) diantaranya merupakan hasil membeli berdasarkan Akta Jual Beli, yang 3 (tiga) lainnya merupakan wasiat yang dibuat oleh Notaris Gati Sudardjo, $\mathrm{SH}$, sedangkan uangRp 8.000.000.000,00 (delapan milyar rupiah) yang ada dibeberapa Bank yaitu BRI, BNI, Danamon, BCA, BTN, Mandiri, Bll dan Panin adalah milik Pemohon (vide T-8 dan T-16 sama dengan bukti P-5).

Dari saksi-saksi yang telah Termohon periksa kemudian dituangkan menjadi Berita Acara Pemeriksaan dalam satu berkas, yang mana keterangan-keterangan para saksi tersebut tidak mengetahui akan terjadinya penggelapan terhadap enam SHM serta tidak ada mengetahui begaimana penipuan dan atau penggelapan uang $\mathrm{Rp}$ 8.000.000.000,00 (delapan milyar rupiah) tersebut.

Jika dikaitkan dengan pengertian saksi berdasarkan Pasal 1 angka 26 KUHAP adalah orang yang dapat memberikan keterangan guna kepentingan penyidikan, penuntutan dan peradilan tentang suatu perkara pidana yang ia dengar sendiri, ia lihat sendiri dan ia alami sendiri; dan pengertian keterangan saksi berdasarkan Pasal 1 angka 27 KUHAP adalah keterangan dari saksi mengenai suatu peristiwa pidana yang ia dengan sendiri, ia lihat sendiri dan ia alami sendiri dengan menyebut 
alasan dari pengetahuannya

itu.

Berdasarkan fakta sebagaimana bukti yang diajukan di persidangan ternyata bukti transfer pemecahan kepada tiga Bank yaitu Danamon, BII dan BTN Purwokerto tidak dapat dibuktikan oleh Termohon, sehingga bukti yang diajukan oleh pelapor yang diduga digunakan oleh Termohon hanyalah berdasarkan 1 (satu) orang saksi yaitu saksi Sutiono (pelapor), sedangkan saksi-saksi yang lainnya adalah keterangannya didasarkan pada pengetahuan dari orang lain dan tidak pernah mengetahui bagaimana asal-usul enam SHM serta uang Rp. 8.000.000.000,00 (delapan milyar rupiah) apakah benar milik pelapor (Sutiono) atau milik Pemohon, dan tidak ada yang mengetahui perpindahan deposit uang tersebut kepada 3 (tiga) Bank yaitu Danamon, BII, dan BTN Purwokerto.

Terhadap bukti-bukti surat yang diajukan oleh Pemohon sebagaimana $\mathrm{P}-1$ sampai dengan P-9, tidak termasuk P10 , yang tanpa aslinya namun kemudian alat bukti yang sama telah diajukan oleh Termohon dengan ditunjukan aslinya sehingga alat bukti surat pemohon menjadi bernilai sehingga menjadi alat bukti yang sah, sehingga dapat dipergunakan dalam pembuktian perkara a quo.

e. Berdasarkan fakta hukum tersebut di atas maka saksisaksi yang diperiksa tersebut baru didasarkan pada satu saksi, sehingga didasarkan kepada Pasal 185 ayat (2) KUHAP seorang saksi saja tidak cukup membuktikan bahwa terdakwa bersalah terhadap perbuatan yang cukup didakwakan kepadanya; sehingga seorang saksi bukanlah saksi (sebagimana asas unus testis nulus testis), sehingga dapat dikhawatirkan alat bukti yang dimiliki oleh Termohon adalah 1 (satu) orang saksi yang menerangkan Pemohon telah melakukan penggelapan dan atau penipuan dan itupun adalah saksi pelapor, dan bukti saksi tersebut belum didukung oleh alat bukti yang sah lainnya sebagaimana ditentukan oleh Pasal 184 KUHAP yaitu selain keterangan saksi, keterangan ahli, surat, petunjuk dan keterangan terdakwa.

f. Oleh karena Termohon telah melakukan penyitaan dalam proses penyidikan, maka terlebih dahulu diuraikan 
477 | J urnal Idea Hukum

Vol. 2 No. 2 Oktober 2016

Magister Hukum Fakultas Hukum Universitas J enderal Soedirman

pengertian dari penyitaan

berdasarkan Pasal 1 angka 16

KUHAP pengertian penyitaan

adalah serangkaian tindakan

penyidik untuk mengambil alih

dan atau menyimpan di bawah

pengua- saannya benda

bergerak atau tidak bergerak,

berwujud atau tidak berwujud

untuk kepen- tingan

pembuktian dalam penyidikan, penuntutan, dan peradilan.

Demi kepentingan

pembuktian dalam perkara a

quo kemudian melakukan

serangkaian tindakan

penyitaan yang terlebih dahulu

Termohon mengeluarkan

Surat Perintah Penyitaan No.

Pol:

SP.Sita/106/V/2012/Reskrim

(vide T-9). Dan untuk sahnya

penyitaan tersebut, Termohon

memohon persetujuan untuk

melakukan penyitaan kepada

Pengadilan Negeri Purwokerto

selanjutnya Pengadilan

mengeluarkan persetujuan

untuk dilakukan penyitaan

berupa Penetapan No.

140/Pen.Pid/2012/PN.Pwt,

tertanggal 04 Juni 2012, serta

Penetapan

No.

132/Pen.Pid/2013/PN.Pwt, tertanggal 03 Juni 2013, dan

Penetapan

No.

153/Pen.Pid/2013/PN.Pwt,

tertanggal 25 Juni 2013 (vide

T-10).
Setelah dilakukan penelitian dalam persidangan yang terkait dengan barang bukti yang harus diperoleh dan dimiliki oleh Termohon yaitu kepemilikan uang sejumlah $R p$ 8.000.000.000,00 (delapan milyar rupiah) sebagimana diduga oleh pelapor (Sutiono) atas diri Pemohon pada tiga Bank yaitu Danamon, Bll dan BTN serta enam SHM diduga adalah milik Sutiono ternyata tidak ada.

Bahwa 6 (enam) SHM yang diduga milik pelapor ternyata adalah milik Pemohon hal ini sebagaimana dibuktikan oleh Pemohon dengan menggunakan Bukti Surat P13, P-14, dan P-15 yaitu pihak Sutiono menggugat Thio Rahardjo (pemohon) pada tanggal 29 Juli 2011 telah mendaftarkan gugatannya tertanggal 27 Juli 2011 kepada Pengadilan Negeri Purwokerto dan telah terdaftar dalam register perkara perdata No. 25/Pdt.G/2011/PN. Pwt yang menjadi objek sengketa adalah enam buah SHM yaitu: SHM No. 01829, 605, 431, 262, 476, dan 185 sesuai dengan SHM yang menjadi pokok laporan pelapor terhadap Pemohon dalam perkara pidana, dengan pertimbangan hukumnya adalah peralihan terhadap 3 
(tiga) buah SHM 262, 02997

(pengganti SHM 476) dan 185 dari Sutiono kepada Thio Rahardjo adalah sah dan menyatakan seluruh gugatan Penggugat (Sutiono) dinyatakan ditolak (vide P-13), dan di tingkat banding diputus tertanggal 13 Agustus 2012 (vide P-14) dan ditingkat Kasasi diputus tertanggal 17 September 2013 (vide P-15) yang diajukan oleh Sutiono (pelapor) dengan amarnya menguatkan putusan Pengabdilan Negeri Purwokerto (Pelapor Sutiono dalam perkara pidana/Penggugat dalam perkara perdata telah dinyatakan sebagai pihak yang kalah karena tidak mampu membuk- tikan dalil gugatannya), dengan demikian dapat disimpulkan bahwa 6 (enam) SHM yang dijadikan objek dalam perkara pidana menjadi tidak dapat dibuktikan $\begin{array}{llll}\text { apabila } & 6 & \text { (enam) SHM }\end{array}$ tersebut adalah milik pelapor (Sutiono).

g. Setelah kurun waktu dari tahun 2011 sampai 2015 ternyata Termohon tidak mampu mengumpulkan bukti-bukti yang harus dilengkapi sebagai syarat bukti permulaan sebagaimana ditentukan dalam Pasal 1 angka 14 KUHAP, dan dengan tidak jelasnya status
Pemohon, maka pada tanggal 15 Mei 2015 Pemohon telah melaporkan seorang anggota Polisi yang bermana IPDA Slamet Husen CP, SH Kanit IV Reskrim Polres Banyumas dengan Laporan Polisi LP/100/V/2015/Yanduan, karena tidak menjalankan tugas secara professional, proporsional, dan prosedural dan tidak menyelesaikan tugas secara tuntas (vide P-11), selanjutnya berdasarkan Surat Panggilan dari KabidPropam Polda Jateng KASUBBIDWABPROF Nomor: Spg/328/VII/2015/Propam tertanggal 02 Juli 2015 telah memanggil Pemohon terkait laporan yang dibuatnya dan telah didengar sebagai saksi.

Selanjutnya mengenai perkembangan hasil laporan dari diri Pelapor (Sutiono), maka Termohon telah memberitahukan

perkembangan hasil penyidikan kepada pelapor pada bulan Maret 2012, 31 Juli 2012, 11 Maret 2013, 28 Juli 2013, Agustus 2013, Pebruari 2014, 13 Mei 2014, 21 April 2014, (vide T-11) dengan didasarkan kepada tindakan termohon telah mengirimkan berkas kepada Kepala Kejaksaan Negeri Purwokerto sejak tanggal 27 Juli 2012, 25 
479 | J urnal Idea Hukum

Vol. 2 No. 2 Oktober 2016

Magister Hukum Fakultas Hukum Universitas J enderal Soedirman

Oktober 2012, 09 Juli 2013, 02

Mei 2014, dan 09 Januari 2015

(vide T-12), yang kemudian

adanya pengembalian berkas

oleh Kejaksaan Negeri

Purwokerto kepada Kepala

Kepolisian Resor Banyumas

tertanggal 02 Agustus 2012,

30 Oktober 2012, 15 Juli 2013,

07 Mei 2014, dan 15 Januari

2015 dengan petunjuk baik

formil maupun materiil yang

belum bisa dipenuhi oleh

Termohon.

h. Berdasarkan pertimbanganpertimbangan tersebut di atas terhadap permasalahan pokok dalam perkara praperadilan ini adalah penetapan diri Pemo= hon sebagai tersangka oleh Termohon bahwa untuk memenuhi dan dapatnya seseorang ditetapkan sebagai seorang tersangka tidaklah cukup didasarkan kepada keterangan pelapor walaupun saksi-saksi yang diajukan lebih dari satu, dalam perkara a quo ada 10 (sepuluh) orang saksi namun keteranganketerangan saksi tersebut tidaklah mendukung keterangan saksi pelapor dan kualitas saksi-saksi tersebut adalah didapat dari pengetahuan orang lain dan tidak mengetahui adanya penipuan ataupun penggelapan sebagaimana disangkakan kepada pemohon sehingga dengan didasarkan pada Pasal 1 angka 14 KUHAP, maka penetapan seorang tersangka didasarkan pada bukti permulaan tidaklah berdasar, serta pada saat Thio Rahardjo (Pemohon) dilaporkan sebagai terlapor berdasarkan Laporan Polisi tertanggal 16 Februari 2011 dan ternyata Termohon tidak mengumpulkan bukti-bukti yang cukup melainkan terburuburu untuk menetapkan Pemohon sebagai Tersangka.

i. Berdasarkan Putusan Mahkamah Konstitusi Nomor 21/PUU/XII/2014 tanggal 28 April 2015 oleh karena Penetapan Tersangka adalah termasuk pranata praperadilan, dengan didasari kepada hakikat pranata praperadilan adalah sebagai bentuk pengawasan dan mechanisme keberatan terhadap proses penegakan hukum yang terkait erat dengan jaminan perlindungan hak asasi manusia, kemudian dalam perjalanannya praperadilan tidak berfungsi secara maksimal karena tidak mampu menjawab permasalahan yang ada dalam proses par-ajudikasi pranata prape- radilan hanya bersifat post fakto sehingga tidak 
sampai pada penyidikan dan pengujiannya hanya bersifat formal yang mengedepankan unsur objektif, sedangkan unsur subjektif tidak dapat diawasi oleh Pengadilan. Guna memberikan kepastian hukum yang adil kepada masyarakat pencari keadilan, dan lebih luas warga negara Indonesia ketika akan ditetapkan seseorang sebagai tersangka oleh penyidik harus melalui proses atau rangkaian tindakan penyidikan dengan cara mengumpulkan bukti yang dengan bukti tersebut penyidik menemukan tersangkanya, dan bukan secara subjektif penyidik menemukan tersangkanya tanpa mengumpulkan bukti.

$$
\text { Sejak ditetapkannya }
$$

Pemohon sebagai Tersangka sejak tanggal 16 Februari 2011 sampai tahun 2015 karena tidak cukup bukti, dan Termohon masih berupaya mengumpulkan bukti-bukti, dengan adanya pengembalian berkas secara bolak-balik oleh Kejaksaan Negeri Purwokerto kepada Kepolisian Resor Banyumas (vide T-13), maka waktu yang dipergunakan oleh Termohon kurang lebih 5 (lima) tahun, menjadi tidak rasional, dan mengakibatkan Pemohon tidak memperoleh kepastian hukum, telah dilanggar Hak Asasi Manusia diri Pemohon.

j. Dengan adanya putusan Praperadilan ini nantinya, diharapkan berdampak positif bagi Pemohon dan Termohon. Terhadap Pemohon akan memperoleh kepastian hukum terhadap sangkaan diri Pemohon apakah telah melakukan perbuatan pidana berdasarkan laporan pelapor (Sutiono), namun ternyata Pemohon tidak cukup bukti dinyatakan sebagai tersangka, di lain sisi dampak positif terhadap Termohon, adalah terkait dengan sikap profesional ditujukan sebagai penyidik, apabila diteruskan dengan tanpa adanya kepastian akan membuat perkara berlarut-larut semakin lama, sehingga dapat dinilai Termohon tidak cukup profesional, sehingga menghindari kesan yang negatif tersebut putusan praperadilan ini akan berdampak positif bagi Termohon.

Berdasarkan

pertimbangan-pertimbangan di atas dapatlah ditarik kesimpulan tindakan Penyidik a quo dengan tanpa dapat mengumpulkan bukti-bukti permulaan terkait dengan 
481 | J urnal Idea Hukum

Vol. 2 No. 2 Oktober 2016

Magister Hukum Fakultas Hukum Universitas J enderal Soedirman

\begin{abstract}
laporan pelapor yang hanya
didasari keterangan pelapor

tanpa didukung oleh alat bukti

yang sah lainnya sebagaimana

ditentukan dalam Pasal 184

KUHAP adalah tindakan yang

keliru dan tidak berdasar

sehingga penetapan

Tersangka atas diri Pemohon

yang dilakukan oleh Termohon

adalah tidak sah.

k. Permasalahan pokok dalam perkara a quo adalah penetapan tersangka atas diri pemohon yang dilakukan oleh Termohon tidak sah, maka dengan demikian petitum permohonan Pemohon nomor 4 (empat) sepatutnyalah untuk dikabulkan.
\end{abstract}

Oleh karena petitum
pokok dikabulkan maka
terhadap petitum ke-2 (dua)
dari permohonan Pemohon
yang menyatakan surat
perintah penyidikan yang
menetapkan Pemohon
sebagai Tersangka oleh
Termohon terkait peristiwa
pidana sebagaimana
dimaksud dalam Pasal 372
dan atau Pasal 378 KUHP
adalah tidak sah dan tidak
berdasar hukum, dan oleh
karenanya penetapan a quo
tidak mempunyai kekuatan
mengikat, maka petitum ke-2
(dua) patutlah
dikabulkan.

I. Petitum selanjutnya mengenai penyidikan yang dilaksanakan oleh Termohon terkait peristiwa pidana sebagimana dimaksud dalam penetapan Tersangka terhadap diri Pemohon sebagaimana dimak- sud dalam Pasal 372 dan atau Pasal 378 KUHP adalah tidak berdasar atas hukum, dan oleh karenanya penyidikan a quo tidak mempunyai kekuatan mengikat, oleh karena penetapan Tersangka terhadap diri Pemohon adalah tidak sah, maka terhadap petitum ke-3 (tiga) permohonan Pemohon patut untuk dikabulkan, sehingga patitum ke-5 (lima) permohonan Pemohon terhadap segala keputusan atau penetapan yang dikeluarkan lebih lanjut oleh Termohon yang berkaitan dengan penetapan Tersangka terhadap diri Pemohon dinyatakan tidak sah, maka petitum tersebut patut untuk dikabulkan.Oleh karena seluruh petitum permohonan praperadilan Pemohon dikabulkan, maka Pemohon haruslah dinyatakan sebagai pihak yang menang.

m. Berdasarkan pertimbangan pada fakta hukum di atas, Pengadilan Negeri Purwokerto 


\begin{tabular}{|c|c|}
\hline yang mengadili perkara & Pemohon yang dilakukan oleh \\
\hline praperadilan & Termohon \\
\hline dalam putusan Nomor & sah;Menyatakan tidak \\
\hline 4/Pid.Pra/2015/PN. Pwt, telah & segala keputusan \\
\hline menjatuhkan putusan sebagai & penetapan yang dike- luark \\
\hline berikut: & lebih lanjut oleh Termoho \\
\hline Eksepsi: & yang berkaitan \\
\hline Menyatakan & penetapan $\quad$ Tersangka \\
\hline Termohon tidak dapat & terhadap diri pemohon ol \\
\hline diterima.Dalam & Termohon;Membebankan \\
\hline Perkara:Menerima & biaya perkara kepada Nega \\
\hline mengabulkan permohonan & sebesar nihil. \\
\hline Pemohon untuk seluruhnya; & Pertimbangan \\
\hline Menyatakan Surat Perintah & Pengadilan Negeri Purwoker \\
\hline Penyidikan yang menetapkan & dalam memutus \\
\hline Pemohon sebagai Tersangka & praperadilan \\
\hline oleh Termohon terkait & 4/Pid.Pra/2015/PN. Pwt, apab \\
\hline peristiwa pidana sebagaimana & ditinjau dari putusan Mahkam \\
\hline dimak- sud dalam Pasal 372 & Konstitusi Nomor \\
\hline $\begin{array}{l}\text { dan/atau } 378 \text { KUHP adalah } \\
\text { tidak sah dan tidak berdasar }\end{array}$ & $\begin{array}{l}\text { XII/2014, dapat diuraikan sebas } \\
\text { berikut: }\end{array}$ \\
\hline
\end{tabular}

atas hukum, dan oleh karenanya penetapan a quo tidak mempunyai kekuatan mengi- kat;Menyatakan penyidikan yang dilaksanakan oleh Termohon terkait peristiwa pidana sebagaimana dimaksud dalam penetapan Tersangka terha- dap diri Pemohon sebagaima- na dimaksud dalam Pasal 372 dan/atau 378 KUHP adalah tidak sah dan tidak berdasar atas hukum, dan oleh karenanya penyidikan a quo tidak mempunyai kekuatan mengikat;Menyatakan penetapan Tersangka atas diri

a. Putusan Nomor 21/PUUXII/2014, tanggal 28 April 2015 pada pokoknya berisi tentang

1) Perluasan objek praperadilan yang ditetapkan dalam Pasal 77 huruf a KUHAP, yaitu termasuk penetapan tersangka, penggeledahan dan penyitaan. Konsekuensi hukumnya berisi sejak tanggal 28 April 2015, objek praperadilan Pasal 77 huruf a KUHAP meliputi tersangka, penggeledahan dan penyitaan.

2) Dalam proses penetapan tersangka harus didasarkan sekurangkurangnya dua alat bukti yang termuat dalam Pasal 184 KUHAP dan disertai dengan pemeriksaan calon 
483 | J urnal Idea Hukum

Vol. 2 No. 2 Oktober 2016

Magister Hukum Fakultas Hukum Universitas J enderal Soedirman

\begin{abstract}
tersangkanya, kecuali terhadap tindak pidana yang penetapan tersangkanya

dimungkinkan dilakukan tanpa kehadirannya (in absentia). Artinya, terhadap tindak pidana yang penetapan tersangkanya dimungkinkan dilakukan tanpa kehadirannya tersebut, tidak diperlukan pemeriksaan calon tersangka.
\end{abstract}

b. Pada pokoknya perkara praperadilan yang diajukan ke Pengadilan Negeri Purwokerto dengan nomor register perkara No. 4/Pid.Pra/2015/PN.Pwt, tanggal 5 Agustus 2015, adalah tentang sah tidaknya penetapan tersangka (pemohon) yang telah ditetapkan oleh termohon penyidik Kepolisian Resor Banyumas, sejak tanggal 16 Februari 2011 berdasarkan Surat Perintah Penyidikan: Spindik No. Pol. S Sidik/67.b/ll/2011/Reskrim.

Dalam putusan praperadilan No. 4/Pid.Pra/2015/PN.Pwt, pada pokoknya diperoleh putusan sebagai berikut:

Dalam

Eksepsi:

Menyatakan

eksepsi

Termohon tidak dapat diterima.Dalam Pokok

Perkara:

1) Menerima dan mengabulkan permohonan Pemohon seluruhnya;
2) Menyatakan Surat Perintah Penyidikan yang menetapkan Pemohon sebagai Tersangka oleh Termohon terkait peristiwa pidana sebagaimana dimaksud dalam Pasal 372 dan/atau 378 KUHP adalah tidak sah dan tidak berdasar atas hukum, dan oleh karenanya penetapan a quo tidak mempunyai kekuatan mengikat;

3) Menyatakan penyidikan yang dilaksanakan oleh Termohon terkait peristiwa pidana sebagaimana dimaksud dalam penetapan Tersangka terhadap diri Pemohon sebagaimana dimaksud dalam Pasal 372 dan/atau 378 KUHP adalah tidak sah dan tidak berdasar atas hukum, dan oleh karenanya penyidikan a quo tidak mempunyai kekuatan mengikat;

4) Menyatakan penetapan Tersangka atas diri Pemohon yang dilakukan oleh Termohon adalah tidak sah;

5) Menyatakan tidak sah segala keputusan atau penetapan yang dikeluarkan lebih lanjut oleh Termohon yang berkaitan dengan penetapan Tersangka terhadap diri pemohon oleh Termohon;

6) Membebankan biaya perkara kepada Negara sebesar nihil.

Terhadap putusan praperadilan di atas, dapat diketahui bahwa Hakim memandang bahwa permohonan pemeriksaan praperadilan yang diajukan pemohon tersebut, sah tidaknya penetapan tersangka adalah merupakan kewenangan praperadilan yang 
didasarkan pada putusan Mahkamah Konstitusi No. 21/PUUXII/2014 tanggal 28 April 2015. Sebelum ada putusan Mahkamah Konstitusi tersebut, penetapan tersangka belum ditetapkan sebagai objek praperadilan sebagaimana diatur dalam Pasal 77 huruf a KUHAP. Hal ini yang menyebabkan antara lain bahwa terhadap permohonan praperadilan yang objeknya tentang sah tidaknya penetapan tersangka yang ajukan sebelum terbitnya putusan Mahkamah Konstitusi No. 21/PUU-XII/2014, akan ditolak oleh Pengadilan, karena tidak termasuk wewenang prapera- dilan. Hal yang menarik dalam perkara yang diteliti penulis, ternyata permohonan praperadilan dalam perkara No. 4/Pid.Pra/2015/PN.Pwt, sebelumnya juga pernah diajukan permohonan prapera- dilan oleh pemohon dengan nomor register perkara No. 01/Pid.Pra/2015/PN. Pwt tanggal 5 Januari 2015.

Dalam putusan praperadilan yang disebut terakhir, Hakim praperadilan Pengadilan Negeri Purwokerto pada pokoknya menyatakan bahwa: "Berdasarkan rumusan bunyi Pasal 1 butir 10 jo Pasal 77 KUHAP, maka petitum permohonan yang memohon agar Pengadilan menyatakan tidak sah penetapan permohon sebagai tersangka karena tidak cukup bukti ... adalah tidak termasuk ruang lingkup wewenang praperadilan". Putusan tersebut dijatuhkan pada tanggal 21 Januari 2015.

Dengan demikian jelas bahwa objek penetapan tersangka sebagai objek yang menjadi ruang lingkup wewenang praperadilan mulai diberlakukan sejak terbitnya putusan Makhamah Konstitusi Nomor: 21/PUU-XII/2014, tanggal 28 April 2015. Indikasi dari berlakunya putusan MK tersebut antara lain bahwa terhadap pengajuan permohonan praperadilan yang objeknya tentang sah tidaknya penetapan tersangka yang diajukan setelah tanggal 28 April 2015, Pengadilan akan menyatakan bahwa permohonan tersebut merupakan kewenangan praperadilan. Namun menurut pendapat penulis, perlu dikaji lebih lanjut terhadap masalah putusan Mahkamah Konstitusi Nomor: $\quad$ 21/PUU-XII/2014 tersebut, berkaitan dengan masalah peneta- pan tersangka yang mana yang menjadi objek praperadilan, sete- lah terbitnya putusan Mahmakah Konstitusi tersebut.

Putusan Mahkamah Konstitusi adalah sejajar dengan produk Undang-undang, karena putusan Mahkamah Konstitusi adalah hasil uji materi terhadap Undang- 
485 | J urnal Idea Hukum

Vol. 2 No. 2 Oktober 2016

Magister Hukum Fakultas Hukum Universitas J enderal Soedirman

undang. Pada asasnya Undang-

undang berlaku untuk masa yang akan datang setelah Undang-

undang tersebut diundangkan sehingga prinsipnya dapat dikatakan bahwa Undang-undang tidak boleh berlaku surut (restoaktif) apalagi dalam bidang hukum pidana. Seperti dikemukakan oleh Sudarto bahwa“... dalam peraturan Undang-undang pidana tidak boleh berlaku resto-aktif (berlaku surut)". 11

Berdasarkan asas-asas hukum tersebut, berarti bahwa putusan Mahkamah Konstitusi Nomor: 21/PUU-XII/2014, hanya berlaku dan mengikat terhadap perkara-perkara permohonan praperadilan tentang penetapan tersangka oleh penegak hukum termasuk penyidik misalnya dalam melakukan penetapan tersangka, setelah terbitnya putusan MK dimaksud, yaitu setelah tanggal 28 April 2015. Sehingga permohonan praperadilan yang diajukan ke pengadilan meskipun diajukan setelah terbitnya putusan MK tersebut, akan tetapi materi atau objek praperadilan misalnya tentang penetapan tersangkanya adalah sudah dilakukan sebelum terbitnya putusan MK tersebut, maka bukan menjadi objek

11 Sudarto, 1990, Hukum Pidana 1, Yayasan Sudarto, Semarang, hlm. 24 praperadilan. Konsekuensinya, penetapan tersangka yang telah dilakukan dalam proses penyidikan sebelum terbitnya putusan MK tersebut tidak menjadi materi objek praperadilan.

Dengan demikian putusan praperadilan Pengadilan Negeri Purwokerto No. 4/Pid.Pra/2015/PN.Pwt, yang memutuskan bahwa penetapan tersangka dilakukan oleh Penyidik Polres Banyumas dengan Sprindik No.Pol. S. Sidik/67.b/ll/2011/Reskrim tanggal 16 Februari 2011, meru- pakan objek praperadilan adalah tidak tepat karena penetapan tersangka oleh penyidik Polres Banyumas dilakukansebelum putusan MK terbit.

Dalam putusan praperadilan No. $\quad$ 4/Pid.Pra/2015/PN.Pwt, terdapat pula pertimbangan yang menilai tentang kualitas keterangan saksi-saksi yang telah dipanggil dan diminta keterangannya oleh penyidik yang dituangkan dalam Berita Acara Pemeriksaan (BAP) saksi, sehingga kete- rangan yang bersifat testimonium de auditu (keterangan yang diperoleh dari orang lain, tidak dapat dianggap sebagai keterangan saksi). Padahal dalam acara persidangan praperadilan, saksisaksi yang terdapat dalam berkas 
perkara penyidikan tersebut, oleh

Hakim praperadilan tidak dihadirkan dan dimintai keteranganya oleh Hakim. Dalam hal ini hakim menilai kualitas keterangan saksi hanya berdasarkan keterangan tertulis dalam BAP, sehingga menurut penulis, kesimpulan hakim praperadilan Pengadilan Negeri Purwokerto tersebut bertentangan dengan ketentuan Pasal 185 ayat (1) KUHAP, yang mengatur: "keterangan saksi ialah apa yang saksi nyatakan di sidang pengadilan". Jadi untuk menilai kualitas keterangan saksi berarti keterangan saksi tersebut harus berupa keterangan yang dinyatakan langsung oleh saksi di depan persidangan, bukan berdasarkan keterangan saksi yang tertulis dalam BAP saksi.

Dengan demikian pendapat hakim praperadilan Pengadilan Negeri Purwokerto dalam putusan No. 4/Pid.Pra/2015/PN.Pwt yang menyatakan bahwa saksi-saksi yang diperiksa penyidik Polres Banyumas merupakan saksi yang bersifat testimonium de auditu adalah tidak benar, dan bertentangan dengan ketentuan Pasal 185 ayat (1) KUHAP.

\section{E. Simpulan dan Saran}

\section{Simpulan}

a. Pokok-pokok pertimbangan dan putusan Hakim Mahka- mah Konstitusi dalam Putusan No. 21/PUU-XII/2014 tanggal 28 April 2015, tentang Pengujian sejumlah Pasal KUHAP khususnya tentang wewenang praperadilan Pasal 77 huruf a KUHAP dan penafsiran frasa "bukti permulaan", "bukti permulaan yang cukup", dan "bukti yang cukup" sebagaimana disebutkan dalam Pasal 1 angka 14, Pasal 17 dan Pasal 21 ayat (1) KUHAP, diputuskan sebagai berikut:

1) Objek kewenangan praperadilan Pasal 77 ayat (1) KUHAP, ditetapkan diperluas termasuk penetapan tersangka, penggeledahan dan penyitaan;

2) Frasa "bukti permulaan","bukti permulaan yang cukup", dan "bukti yang cukup" sebagaimana ditentukan dalam Pasal 1 angka 14, Pasal 17, dan Pasal 21 ayat (1) KUHAP, harus dimaknai minimal dua alat bukti yang termuat dalam Pasal 184 KUHAP;

3) Proses penetapan tersangka oleh penyidik harus didasarkan pada minimal dua alat bukti yang termuat dalam Pasal 184 KUHAP (keterangan saksi; keterangan ahli; surat; petunjuk; keterangan terdakwa).

b. Pertimbangan Hakim

Pengadilan Negeri Purwokerto dalam perkara praperadilan No. 4/Pid.pra/2015/PN. Pwt, ditinjau dari pertimbangan 
487 | J urnal Idea Hukum

Vol. 2 No. 2 Oktober 2016

Magister Hukum Fakultas Hukum Universitas J enderal Soedirman

putusan Hakim Mahkamah
Konstitusi No. 21/PUU-
XII/2014, dapat dikemukakan
sebagai berikut:

1) Bahwa benar sejak tanggal 28 April 2015, melalui putusan Mahkamah Konstitusi No. 21/PUUXII/2014, wewenang praperadilan dalam Pasal 77 huruf a KUHAP diperluas menjadi termasuk penetapan tersangka, penggeledahan dan penyitaan. Namun seharusnya putusan Mahkamah Konstitusi tersebut untuk mengadili perkaraperkara permohonan praperadilan tentang keabsahan penetapan tersangka yang ditetapkan setelah keluarnya putusan Mahka- mah Konstitusi dimaksud, bukan terhadap penetapan tersangka oleh penyidik sebelum keluarnya putusan Mahkamah Konstitusi hal ini sejalan dengan asas bahwa Undang-undang tidak berlaku surut (non restroaktif).

Oleh karena itu putusan praperadilan Pengadilan Negeri Purwokerto No. 4/Pid.pra/2015/PN. Pwt, yang kemudian menyatakan penetapan tersangka yang dilakukan oleh penyidik tidak sah, adalah tidak tepat dan bertentangan dengan asas non restroaktif.

2) Pertimbangan Hakim Praperadilan No. 4/Pid.pra/2015/PN.

Pwt,dalam membuktikan ada tidaknya minimal dua alat bukti dalam proses penetapan tersangka oleh penyidik Polres Banyumas, khususnya dalam menilai kualitas keterangan saksisaksi yang sudah diperiksa oleh penyidik, tidak didasarkan pada pemeriksaan saksi-saksi berdasarkan ketera -ngan saksi di depan persidangan, melainkan hanya mendasarkan pada berita acara keterangan saksi dalam berkas perkara.

Hal ini bertentangan dengan ketentuan Pasal 185 ayat (1) KUHAP, bahwa : "Keterangan saksi sebagai alat bukti ialah apa yang saksi nyatakan di sidingpengadilan".

Sehingga tidak tepat apabila kemudian Hakim praperadilan menyimpulkan bahwa keterangan saksisaksi tersebut bersifat testimonium de auditu (keterangan yang diperoleh dari orang lain) sehingga tidak termasuk keterangan saksi sebagaimana ditentukan dalam Pasal 184 KUHAP.

\section{Saran}

Putusan Mahkamah

Konstitusi No. 21/PUU-XII/2014 seyogyanya untuk mengadili perkara praperadilan tentang sah tidaknya penetapan tersangka terhadap perkara - perkara penyidikan yang dilakukan setelah keluarnya putusan Mahkamah Konstitusi tersebut, yaitu setelah tanggal 28 April 2015.

\section{DAFTAR PUSTAKA}

Sholehudin, M., 2004. Sistem Sanksi dalam Hukm Pidana. Ide Dasar Doble Track System \& Implementasinya, Raja Grafindo, Jakarta.

Soekanto, Soerjono, dan Sri Mamudji, 2007. Penelitian Hukum Normatif 
Suatu Tinjauan Singkat, Raja Grafindo Persada, Jakarta.

Soemitro, Ronny Hanitijo, 1988. Metode Penelitian Hukum dan Yurimetri. Ghalia Indonesia, Jakarta.

Soeparmono, R., 2003. Praperadilan dan Penggabungan Perkara Gugatan Ganti Kerugian Dalam KUHAP, Mandar Maju, Bandung.

Sudarto, 1990, Hukum Pidana 1, Yayasan Sudarto, Semarang.

Sunggono, Bambang, 2006. Metode Penelitian Hukum, Raja Grafindo Persada, Jakarta.

Tanusubroto, S., 2006.Peranan Praperadilan dalam Hukum Acara Pidana, Alumni, Bandung.

Alkostar, Artidjo,2008 Dissenting Opinion, Concurring Opinion dan Pertanggungjawaban Hakim, Majalah Varia Peradilan No. 268 Edisi Maret 2008, IKAHI, Jakarta.

Rizki, Muhammad, 2014. E pistemologi Nalar dalam Pertimbangan Hukum, Majalah Hukum Varia Peradilan No. 346, Edisi September 2014, Mahkamah Agung RI, Jakarta.

Subechi, Imam, 2014. Putusan Hakim dalam Pembaharuan Hukum, Majalah Hukum Varia Peradilan. No. 347 Edisi Oktober 2014, MARI, Jakarta. 